\title{
Revisiting intertextuality and humour: fresh perspectives on a classic topic
}

\author{
Villy Tsakona \\ National and Kapodistrian University of Athens, Greece \\ villytsa@,otenet.gr, vtsakona@ecd.uoa.gr
}

\section{Jan Chovanec}

Masaryk University, Brno, The Czech Republic

chovanec@phil.muni.cz

\begin{abstract}
In humour research, intertextuality has been extensively studied with the aim of understanding how humorous texts are constructed on the basis of previous texts. In this paper, we elaborate on the sociopragmatic functions of intertextuality, pointing out not only how humorous texts rely on previous texts and background knowledge, but also what sociopragmatic functions intertextuality serves in actual communicative situations, e.g. the effect the recognition (or not) of intertextual references has on the segmentation of recipients into various groups. To this end, the paper discusses intertextuality in relation to such traditional concepts as textuality and genre, and adds a focus on the speaker's intention and the recipient's interpretation. The paper serves as a framing introduction to six other papers in the special issue on the topic of "Intertextuality and humour", articulating a common research position and arguing for the extension of scholarly attention to such applied domains as critical literacy education, marketing communication, and the legal framework regulating the creation and reception of humorous texts and artefacts.
\end{abstract}

Keywords: intertextuality, sociopragmatics, genre, interdiscursivity, ingroup.

\section{Introduction}

Texts, whether they be literary or non-literary, are viewed by modern theorists as lacking in any kind of independent meaning. They are what theorists now call intertextual. The act of reading, theorists claim, plunges us into a network of textual relations. To interpret a text, to discover its meaning, or meanings, is to trace those relations. Reading thus becomes a process of moving between texts. Meaning becomes something which exists between a text and all the other texts to which it refers and relates, moving out from the independent text into a network of textual relations. The text becomes the intertext. 
A special issue on humour and intertextuality may not sound as original enough to some readers: what is new to say about humour and intertextuality? Attardo (2001: 61) may have captured everything in a single sentence: "some concepts, such as 'intertextuality', [...] play a significant part in the development of a broad theory of humorous texts". Other scholars such as Raskin (1985) and Norrick $(1989,1993)$ have also underlined the importance of recognising and 'correctly' interpreting allusions included in humorous texts, so as to avoid humour failure, miscommunication, and social distance among interlocutors. Whatever linguistic approach one takes to the study of humorous texts, be it the traditional structural-textual, cognitive, or the more interaction-based sociopragmatic analysis, it is indisputable that intertextuality - in one form or another - lies at the very heart of humour.

Arguably, part of the problem with exploring the issue of humour and intertextuality is the multitude of forms that humour can take. It comes in quite diverse formats, ranging from relatively simple textual forms to complex interactive and technology-mediated communicative and behavioural practices. Understandably, the role of intertextuality is different in different humorous genres. Canned jokes, for instance, constitute relatively selfcontained units, often with a predictable structure (Raskin 1985; Chłopicki 2020), where humorous effect is generated upon the recipient's recognition of the structure and type of the joke. Intertextually, such jokes also rely on the anticipated shared background knowledge that is necessary for the processing and understanding of the underlying humorous scripts (Tsakona 2018a, 2018b, this issue). The same applies to another traditional humorous genre cartoons - that call for a multimodal approach to the study of the role of intertextuality due to their combination of verbal and visual modes (El Refaie 2009; Tsakona 2009). At present, another of such prima facie humorous genres can be seen in humorous digital memes, which have become almost omnipresent in digital communication. Establishing intertextual connections is undoubtedly the sine qua non for their creation and interpretation (see among others Shifman 2014; Laineste \& Voolaid 2016; Piata 2018, to appear; Yus 2018; Dynel \& Poppi 2019; Vásquez 2019).

At the same time, due to intertextuality, canned jokes, cartoons, and memes may become part of higher-level humorous (e.g. a stand-up routine) as well as non-humorous genres (e.g. a political speech) that involve the telling of a joke, or the use of a cartoon or a meme for that matter, for a particular reason, e.g. to reduce tension at a workplace meeting, to provide an acceptable form of criticism, to mock and ridicule others, to secure acknowledgement in one's group, etc. In the digital world, a humorous act may simply serve to attract attention (Vásquez 2019: 173), as well as help to create an atmosphere of co-participation. Participating with the content, e.g. by sharing, liking, and emulating existing humorous artefacts, constitutes a novel form of intertextuality, particularly as regards the online engagement with technologymediated content in the social media (Chovanec \& Dynel 2015; Tsakona 2018c).

For those reasons, our preferred approach to the analysis of intertextuality in humorous data is based in sociopragmatics, i.e. the identification and interpretation of the phenomena within the small-scale communicative context (on the level of a particular interaction as well as a history of personal interactions) and the large-scale context of broader social patterns (see among others Norrick \& Chiaro 2009; Tsakona \& Chovanec 2018; Tsakona 2020a).

There has already been some research on humour and intertextuality bringing to the surface important points concerning its sociopragmatic analysis. In the present undertaking, however, we decided to revisit the issue as an exercise on intertextuality itself: by drawing on findings and establishing intertextual connections with previous research, we thereby attempt to highlight the pervasiveness of intertextuality in humour. Simultaneously, we would like to remind our potential readers that all research cannot but be an exercise on intertextuality. Researchers rely on previous discourse (e.g. books, articles, data, courses, style guides) to 
produce their own. It is in this sense that "the term intertextuality promotes a new vision of meaning, and thus of authorship and reading: a vision resistant to ingrained notions of originality, uniqueness, singularity and autonomy" (Allen 2000: 6).

The exercises on intertextuality included in this special issue emerge from our effort to bring to the limelight some aspects or effects of the interplay between humour and intertextuality that have attracted our attention and, in our view, allude and add to the old, open debates on intertextuality and/or humour. To put it in Allen's terms (see the quotations above), our papers cannot have any independent meaning without references to earlier works but, most importantly, gave us the opportunity to plunge into a network of texts concerning intertextuality and/or humour, to move from one text to another, and to hopefully swim safely back to a shore. Moreover, whether implicitly or explicitly, what all the papers of this special issue perform is an intertextual analysis of the datasets involved, which "identifies genres and discourses that the text[s] draws upon, and the ways they are articulated together" (Fairclough 2000: 170).

So here, we first outline some of the key aspects of intertextuality and their relevance for sociopragmatic research (Section 2), and then elaborate on the role of intertextuality in the study of humorous texts (Section 3). We concentrate on the social effects of intertextual references in texts, their perception, and recipients' understanding of the all-too-often subtle implications of intertextuality. We note how they serve multiple goals, ranging from the construction of ingroups (i.e. those 'in the know') to such essentially political aims as the critical and subversive potential of humour to question and undermine existing power structures. Finally, Section (4) concludes with an overview of the papers, outlining how they develop the general themes and contribute to the research issues outlined in this chapter.

\section{On the sociopragmatics of intertextuality}

In his book on intertextuality, Gasparov (2010: 16) explains intertextuality in a manner that could perhaps be characterised as the simplest possible one: "speech is primarily a product of speech". He further explains that "the prevalent mode of speakers' linguistic activity can be called "intertextual"" and that "every new artefact of speech emerges out of the material provided by previous speech experience" (Gasparov 2010: 3, 16). Obviously influenced by and echoing Bakhtin (1986/1979), Gasparov (2010) underlines in very few words the pervasiveness of intertextuality as well as the fact that intertextuality is a prerequisite for every form of discourse. In what follows, we discuss various aspects of intertextuality that have attracted scholarly attention within pragmatics, sociolinguistics, and adjacent fields.

\subsection{Intertextuality as a standard of textuality}

In line with such a perspective, and chronologically somewhere between Bakhtin (1986/1979) and Gasparov (2010), de Beaugrande \& Dressler (1981) propose that intertextuality is one of the seven standards of textuality, the other six being cohesion, coherence, intentionality, acceptability, informativity, and situationality. They also claim that "[t]hese standards function as CONSTITUTIVE PRINCIPLES [...] of textual communication: they define and create the form of behaviour identifiable as textual communicating, and if they are defied, that form of behaviour will break down" (de Beaugrande \& Dressler 1981: 11, emphasis in the original). In their account of intertextuality, de Beaugrande \& Dressler (1981: 182-208) distinguish between two main types of intertextuality: the first one relates to generic similarities among texts, which allow for the classification of texts into genres emerging in specific contexts and serving specific social functions and goals; and the second one pertains to intertextual 
references to, and recontextualisations of, extracts from already (often well-known) texts into new ones presupposing interlocutors' familiarity with prior texts.

Such accounts of intertextuality confirm that it is indeed impossible to produce any kind of discourse without establishing some kind of intertextual connection between what we currently say or write and what we or other people have said or written in the more or less distant past. Intertextuality provides us with the building blocks of our discourse. In this context, relevant research has gone further than that by looking into the sociopragmatic functions served by connecting different texts through intertextual references. Such research usually concentrates on intertextuality that is evident, salient, or even marked (e.g. through quotation marks or through explicit mentions of the source text) to create specific discoursal effects. In other words, researchers mostly focus on instances where intertextuality becomes a more or less noticeable feature of discourse in speakers' effort to achieve certain communicative goals (see manifest intertextuality in Fairclough 1992: 104, 118-123; see also Shilikhina this issue).

\subsection{Sociopragmatic functions of intertextuality}

In this Section, we briefly summarise some main findings of relevant studies on the sociopragmatics of intertextuality (see Bakhtin 1986/1979; Kristeva 1980; Briggs \& Bauman 1992: 141, 147, 148; Fairclough 1992: 101-136; Bauman 2004: 1, 4-5, 8; Adami 2012; Bhatia 2017; Hale 2018b: 510-511, 516-518; Badarneh 2020).

One of the most discussed sociopragmatic functions of intertextuality is its potential to divide interlocutors into ingroup and outgroup members. Intertextual references presuppose shared sociocultural knowledge among interlocutors and cannot therefore be recognised and understood by everybody. Those who include allusions in their texts position their recipients as ingroup members, namely as capable of reaching the 'intended' interpretation of the allusions by evoking the 'correct' previous texts and by making the same interconnections as the text producers. Those recipients who cannot or will not do that are positioned as outgroup members, since they do not share the same sociocultural knowledge with the text producers. In this sense, intertextuality acquires a hegemonic and/or elitist function (see Fairclough 1992 and Adami 2012 respectively; see also Werner 2004) by dividing interlocutors into those 'in the know' and those 'out of the know'.

Simultaneously, intertextuality may have a self-enhancing motive and effect, especially when intertextual connections are established with prestigious or culturally-significant prior texts. When either text producers or text recipients present themselves as able to process intertextual references to such texts, they manage to portray themselves as 'educated' and 'literate' individuals, who are familiar with 'important', 'central', or currently 'fashionable' intertexts. Intertextuality may thus have a self-aggrandising effect (see also Tsakona this issue). For example, a research paper on intertextuality including an explicit intertextual reference to Bakhtin's (1986/1979) seminal work may appear as more well-conversed in the relevant literature than a paper without such a reference. Concurrently, the author of the paper could thus accrue prestige for being able to establish the intertextual connection and the recipient could do the same for grasping what it refers to. In general, the ability to make such relevant and correct intertextual connections is - quite unsurprisingly - particularly crucial in academic writing: it is, for instance, one of the rhetorical skills distinguishing novice writers from more experienced scholars.

Intertextual connections with other texts may be established as a means to convey stance and criticism. Speakers may resort to pre-existing texts and their authors either to criticise them or to criticise third parties through using someone else's (who is usually famous and esteemed) words. Such a move may make criticism sound more justified, substantiated, and 
'objective', and/or may allow speakers to distance themselves from the criticism by pretending that these are not their own words. In the latter case, intertextual allusions may constitute politeness strategies (in Brown \& Levinson's 1987 sense), since they could mitigate criticism or even offence (Badarneh 2020). In academic discourse, such intertextuality serves the writer, once again, to position oneself with respect to previous scholarship, typically in order to establish a research niche, and thus build one's identity and credibility as an expert member of the academic community (Flowerdew \& Wang 2017).

\subsection{Intertextuality and genre}

Intertextuality is also an important mechanism for genre renewal and the creation of new genres: speakers' generic knowledge and their tendency to bend generic conventions allows for the recontextualisation of generic features so that hybridised texts are produced and new genres are created (see among others Fairclough, 1992: 221; Tsakona 2017b: 492-494). This conception builds on de Beaugrande \& Dressler's (1981) second dimension of intertextuality (see Section 2.1), namely the generic similarity between texts - a dimension that tends to be overlooked in many accounts of intertextuality that concentrate on the formal aspects of intertextuality, as manifested by the appropriation of the words, meanings, and textual segments and realised by means of references and allusions.

Readers typically become aware of this dimension of intertextuality when the generic conventions are not adhered to and the resulting text becomes marked as regards its genre. What is at stake here is a phenomenon known as constitutive intertextuality that Fairclough (1992: 124) terms interdiscursivity. Interdiscursivity is manifested in texts whenever their authors mix conventions coming from different genres. Such mixing can lead to (a) textual heterogeneity, with texts composed of elements of various discourses, (b) modification of existing genres and discourses, and (c) the emergence of new genres and discourses that may gradually become established within a given community. As a result of these processes, speakers may end up constructing new and probably more effective ways of expressing themselves and attaining their social goals (Shilikhina this issue). Such creative generic practices have a host of interactional sociopragmatic functions: for instance, they may be related to speakers' wish to promote themselves, to criticise others (and their ways of speaking or writing), and eventually to draw boundaries between those who have access to certain 'new' genres and those who do not (see Section 2.2).

\subsection{Intertextuality, intention, and interpretation}

Such perspectives on intertextuality, albeit insightful and enlightening, tend to overlook two fundamental sociopragmatic aspects of discourse. First, speakers' intention does not necessarily determine recipients' interpretation; and, second, recipients who may not reach the 'intended' interpretation may eventually reach a different one. In other words, the emphasis placed (by speakers, recipients, and researchers alike) on the importance of background knowledge for understanding discourse (including its intertextual allusions) implies that there is a 'single', 'correct' meaning of a certain utterance or text: beyond that, there is only miscommunication and failure to comprehend. But is this so?

Like other textuality standards, such as coherence and acceptability (see de Beaugrande \& Dressler 1981 in Section 2.1), intertextuality is not a property of the text but the result of speakers'/recipients' interpretative effort. Each of them retrieves his/her own background knowledge in the form of scripts, schemata, frames, etc. ${ }^{1}$ which may eventually lead to diverse

\footnotetext{
1 "The script is a large chunk of semantic information surrounding the word or evoked by it. [...] Every speaker has internalised rather a large repertoire of scripts [...] which represent his/her knowledge of certain
} 
or even opposing meanings. So, recipients construct and not merely re-construct intertextual connections. Briggs \& Bauman (1992: 157) point out the "fallacy in assuming that intertextual relations are established by performers or authors alone: a crucial part of the process of constructing intertextual relations may be undertaken by the audience" (our emphasis; see also Allen 2000: 209; Bauman 2004: 5; Conradie 2012: 294, 298; Hale 2018b: 511-512).

The active construction - rather than reconstruction - of intertextual connections and, ultimately, meanings has two possible outcomes. Instead of arriving at some prior intended meanings of texts (what Bell 2011: 535 refers to as "reducing interpretation to the divination of that [i.e. the author's] intention"), recipients not only freely construct their own interpretations of texts but also consciously arrive at resistant readings that go counter to what they perceive to be the texts' (and their authors') intended meanings. The first of these situations encapsulates a hermeneutical process of textual reading and discourse interpretation, which, according to Bell (2011), challenges and discards the dominance of author intention and structuralist analysis of texts in favour of affirming the validity of alternative readings. Discourse analysis (or, rather, interpretation) is then achieved through a combination of contextualised social analysis of socio-cognitive processes, the detailing of the macropropositions of a text, and the social and ideological critique that leads to the appropriation of texts (with the ultimate goal being not just understanding but ownership, in Bell's 2011 terms). However, being based on and deriving from textual and intertextual evidence, the alternative readings should not be equated with limitless polysemy (Bell 2011: 536) that some constructivist approaches might imply.

The second category concerns meanings that are more divergent. Fairclough (1992: 134136) calls those meanings which more or less deviate from the 'intended' ones resistant readings. Such readings come from recipients being reluctant to accept text producers' sociocultural and ideological presuppositions and "may disarticulate to one extent or another the intertextual articulation of a text" (Fairclough 1992: 136). Author-independent and resistant readings are neither rare nor marked. They are in fact inevitable, if we take into consideration that recipients often come from different sociocultural groups and cannot possibly share exactly the same knowledge, ideologies, values, and views (Hale 2018b: 514). Allen (2000: 3-4) further comments on the liberating aspect of such readings:

the term intertextuality was initially employed by poststructuralist theorists and critics in an attempt to disrupt notions of stable meaning and objective interpretation. [...] Authors, therefore, cannot be held responsible for the multiple meanings readers can discover within literary texts. Barthes [1967] views such a situation as a liberation for the readers; a liberation from the traditional power and authority of the figure of the 'author', who is now 'dead'.

Furthermore, such readings are directly related to the boundary-marking function of intertextuality which divides interlocutors into ingroup and outgroup members (see Section 2.2).

Last but not least, there is one more aspect of intertextuality that tends to be overlooked and perhaps underestimated within sociopragmatic research, namely its pervasiveness. Even if some intertextual references and allusions are easy to spot and may be even marked and very prominent in the text (see Section 2.1), they are not the only ones we use or come across while processing discourse. If "speech is primarily a product of speech" (Gasparov 2010: 16; see

routines, standard procedures, basic situations, etc. [...] What is labelled here 'script' has been called 'schema', 'frame' [...], etc.” (Raskin 1985: 81; see also Section 3).

2 Allen (2000: 4) interestingly notes that poststructuralism and structuralism view intertextuality differently: "poststructuralist critics employ the term intertextuality to disrupt notions of meaning, whilst structuralist critics employ the same term to locate and even fix literary meaning" (our emphasis). 
above), then, one might be inclined to adopt the Bakhtinian position of extreme dialogism or heteroglossia: there is nothing we can say or write that is our own - every word and utterance echoes previous uses. In this light, talking about intertextuality as a 'distinct' phenomenon, marking, detecting, or investigating it in discourse might seem to be a more or less futile endeavour. Should we accept that intertextuality can be controlled or restricted, then we might end up controlling or restricting everything we say or write. Thus, when investigating intertextuality, we are inevitably concerned only with those aspects of intertextuality that involve attestable references to other non-present but recognisable texts because a broader conception would be analytically inoperative (cf. Kotthoff 2002: 208, who adopts a similarly limiting approach to the study of intertextual quotations and irony).

\section{On the sociopragmatics of humour and intertextuality}

If intertextuality is ubiquitous in discourse, it must be ubiquitous in humour as well. After all, the very concept of incongruity or script opposition, which is used to account for most (if not all) humorous instances (Raskin 1985; Attardo 1994, 2001), relies on intertextuality. When interpreting humorous texts, recipients evoke specific scripts, namely previous experiences and knowledge of the world (including, and/or included in, previous texts) to make sense of the humorous material at hand. Such previous intertextual experience and knowledge become the benchmark against which the second, incongruous script of interpretation creating the humorous effect surfaces. In other words, incongruity or script opposition cannot actually be established without reference to previous (con)texts, which are considered as expected, conventional, or normal in some sense. Therefore, establishing intertextual connections with previous (con)texts determines what is incompatible or incongruous in a given (con)text. In this sense, intertextuality lies at the heart of humour: there cannot be any humorous text that is not intertextual (see also Tsakona 2018a: 90, 2018b: 2-3).

The interplay between humour and intertextuality has for some time now attracted scholarly attention, especially since intertextual references seem to render humour hard(er) to understand. As a matter of fact, more or less similar sociopragmatic functions have been identified for such interplay to the ones discussed in Section (2) about intertextuality in general (the following discussion draws mainly on Sacks 1974; Raskin 1985: 46, 136, 138139; Sherzer 1985; Norrick 1989: 117-118, 120-130, 1993: 44, 61, 69-72, 98, 109; Werner 2004; Laineste \& Voolaid 2016; Mazurek-Przybylska 2016: 81-83, 91; Tsakona 2018a, 2018b, 2019).

\subsection{Some main sociopragmatic functions of intertextuality in humour}

First of all, intertextual references in humorous discourse have been perceived and investigated as a way to test for common ground and hence to divide interlocutors into those 'in the know' and those 'out of the know'. Depending on their sociocultural knowledge, in particular on their ability to 'properly' decipher allusions included in humorous texts, interlocutors may get to know each other and eventually strengthen their solidarity bonds or be driven apart (see also Chovanec 2018; Pinar-Sanz this issue; Tsakona this issue).

Concurrently, those who are 'in the know' may thus increase their social prestige and feel, or be perceived as, superior to those 'out of the know', exactly for being familiar with various more or less prestigious intertexts. Failure to 'correctly' process the intertextual reference included in a humorous text may turn out to be an embarrassing or disparaging experience for the recipient, damaging his/her face (in Brown \& Levinson's 1987 sense). The situation becomes interactionally even more complicated when the humour producer uses irony and sarcasm (e.g. as a form of overt untruthfulness; see Kotthoff 2002; Dynel 2018), 
since such humorous mechanisms not only operate with the recipient's assumed ability to recognise and identify intertextuality, but also depend on the ability to juxtapose the multiple meanings emerging from humorous texts.

The evaluative function of intertextuality also appears to be salient in humorous texts, especially in parody, which relies on, and distorts, previous texts or genres to encourage a deconstructing, critical perspective on them (Bakhtin 1986: 80; de Beaugrande \& Dressler 1981: 11; Ross 1998: 47-51: Allen 2000: 189; Attardo 2001: 71; Bauman 2004: 5). The same could be suggested for political satire or other forms of political humour, which more often than not draw on political texts, politicians' statements or speeches, etc. to discredit them and portray them as ridiculous or absurd (see among others Popa 2011; Watters 2011; Tsakona 2017a, 2017d, this issue; Astapova this issue; Capelotti this issue; Pinar-Sanz this issue; Shilikhina this issue).

\subsection{Intertextuality and humorous genres}

Intertextuality has been explored as an important parameter for the classification of humorous texts either in joke cycles, namely groups of thematically related humorous texts, or in various humorous genres, such as aphorisms, riddle-jokes, narrative jokes, humorous anecdotes, cartoons, sitcoms, stand-up comedy, among many others (see Attardo \& Chabanne 1992; Tsakona 2017b, 2020b: 170). In this context, an intriguing category for humour scholars appears to be that of second-generation jokes or para-jokes (Attardo 2001: 70) or meta-jokes (Astapova this issue), which play on the generic conventions and content of previous jokes and presuppose interlocutors' familiarity with already existing humorous texts. Such jokes about jokes turn out to be valuable sources of information about how humour is perceived, responded to, and further manipulated within a specific sociocultural context (see Astapova this issue, and references therein).

In addition, creating intertextual links among genres and the ensuing generic mixing contribute to the emergence of novel or creative humorous texts and genres. This "generic crossing in a text" (Coutinho \& Miranda 2009: 44) has been shown to constitute one of the most common strategies for the production of humour (see among others Tsiplakou \& Ioannidou 2012; Antonopoulou et al. 2015; Archakis et al. 2015; Tsakona 2020a: 66-69, 100$102,2020 \mathrm{~b}$; Shilikhina this issue). Needless to say, the processing of humorous texts is easier for those who are already familiar with other humorous texts coming from the same cycle, belonging to the same humorous genres, or constituting the 'original' source on which the derivative meta-joke was built.

\subsection{Intertextuality, humorous intention, and interpretation}

The possibility that humour may fail due to recipients' inability to detect and 'properly' interpret intertextual allusions included in humorous texts has not, of course, escaped humour scholars' attention (see among others Raskin 1985: 136, 138; Norrick 1989: 127; Werner 2004; Bell 2015; Kuipers 2020). Besides the loss of social prestige or face for those who appear to be 'out of the know', such failure may result in more or less serious communication problems and misunderstandings among interlocutors. It is, however, often overlooked that, when humour recipients fail to 'properly' identify and process an allusion, this does not necessarily entail that they will not reach any interpretation at all. By evoking most probably different (or even opposing) scripts from the expected ones, such recipients may come up with different and often serious readings of texts intended to be perceived as humorous, thus making some sense of discourse according to their own sociocultural knowledge, values, and ideologies (see Kramer 2011; Laineste 2011; Tsakona 2013, 2017c, 2019, 2020a; Capelotti 
this issue; Dore this issue). In other words, in such cases, humour may have not been perceived as such, but this does not mean that communication has completely collapsed.

At the same time, the converse situation applies as well, namely when non-humorous texts are found to be funny by the recipients, with humour sometimes having damaging consequences for the speaker (Chovanec 2016; Tsakona \& Tsami in prep.). Such unintended humour presents an interesting and largely overlooked area of humour studies, although a similar communicative mismatch is found in failed humour (Bell 2015; see above). From the speaker's perspective, such a situation constitutes an act of miscommunication or a communicative infelicity or even failed seriousness (Chovanec in print) since no humour was intended. The humorous reception is possible due to recipients' perceiving various kinds of incongruities or reading additional scripts into the original non-humorous utterances.

All this confirms the validity of alternative readings (see Bell 2011 in Section 2.4) that are independent of the original speaker's intentions, as well as the need to consider humour as a phenomenon that is, at least partly, constructed or co-constructed in reception contexts (Chovanec \& Tsakona 2018). Such cases confirm the postmodern perspective on discourse and intertextuality suggesting that recipients will establish intertextual connections while processing discourse, even if not the expected, 'correct' ones (see Section 2.4). Furthermore, such divergent readings may eventually be resistant ones (see Fairclough 1992 also in Section 2.4) in the sense that recipients do not acquiesce to, or comply with, the presuppositions proposed by the producers of humorous discourse, and retrieve other scripts for framing and interpreting aspects of social reality. As a result, 'resisted humour' may emerge, where the humorous intention of the producer is quite clearly identified by the recipient but no humorous effect is demonstrated externally on the reception side (Chovanec 2016; Hale 2018a). In such cases, the reception of the intentional humorous act may clash with recipient's personal belief system or the dominant social norms and ideologies prevalent in the society at a particular time (e.g. political correctness influencing recipients' reactions to such socially problematic issues as racist humour). The avoidance of acknowledging some humorous act by laughing or reciprocating it, etc. may be related, among other things, to the perception of the divisive nature of the humorous text (Hale 2018a) or one's desire not to condone a problematic ideology on which a given humorous text depends (Tsakona 2019, 2020a). Eventually, it may be complemented with the recipient's explicit denial of the funniness of such humorous acts.

A final note concerns the efforts occasionally made to put limits to the use of intertextual references for humorous purposes. Fairclough (1992: 102) suggests that, in general, intertextuality "is socially limited and constrained upon relations of power". This is attested when humour is negatively criticised, publicly denounced, censored, or even banned for moral, political, religious, or other reasons (see among others Lewis 2008; Smith 2009; Tsakona 2013, 2020a; Constantinou 2019; Astapova this issue; Capelotti this issue; Dore this issue). Humourists may not always be free to draw from all kinds of texts to create their utterances or texts. Nevertheless, such situations occasionally backfire: censored humour tends to become highly political and assume a subversive role in society, chipping away at the dominant power structures and helping to remove their legitimacy, particularly in nondemocratic societies (Davies 2007; Krikman 2009; Chen 2013).

More often than before, such restrictions become the object of open public debates in contemporary globalised societies, where, for example, humorous texts created in a certain part of the world may have significant repercussions far away from that part, or where the internet and the social media become unstoppable sources of humour including 'inappropriate', 'blasphemous', 'or 'dangerous' intertextual references. Public debates and legislation may attempt to take into consideration the views and positionings of all the parties involved, but so far it seems that 'dangerous', 'blasphemous', 'inappropriate', and eventually 'illegal' intertextuality is not always easy to define and restrain, whether in humorous or in 
non-humorous texts. Such difficulty most probably results from the fact that participants in public debates and legislators often perceive and define intertextuality as a much narrower and easily detectable phenomenon than it actually is. When one realises its pervasiveness or multiplicity, one would also be aware of its elusiveness and resistance to boundaries. It is therefore not accidental that restrictions attempted or imposed on intertextuality are often framed and resisted as restrictions on the freedom of expression.

\section{Overview of papers}

While the papers included in this special issue discuss the phenomenon of intertextuality in humour from several perspectives, they are mutually complementary in addressing similar themes. The papers are grouped in a coherent way as follows: the first two papers emphasise the role of background knowledge in the production and processing of intertextuality in humour (Pinar-Sanz; Tsakona), the other two papers focus on the creation of new texts and genres (Astapova; Shilikhina), and the last two papers turn attention to problematic issues, namely the failure of intended humorous effect and official restrictions placed on the production and circulation of humorous texts (Dore; Capelotti). All the papers share a common preoccupation with tracing how intertextual references are deployed in humorous texts, on the one hand, and processed by various groups of recipients, on the other.

In the first paper, María Jesús Pinar Sanz considers visual metaphors and metonymies in political cartoons, tracing how they establish intertextual links to historical as well as contemporary social and political events, cultural artefacts, etc. The paper argues that the appreciation of humour depends on the audience's ability to have access to specific background knowledge, which is sometimes of a rather sophisticated nature. Humour is thus accessible to educated recipients who are 'in the know' and can process and appreciate the allusions and intertextual references adopted by the political cartoonist.

The idea of how different levels of access to background knowledge affect the various groups of humour recipients is also the central point in the second paper by Villy Tsakona. Analysing political jokes, she approaches the data through the lens of cultural and critical literacy, identifying multiple sets of opposing groups that are constituted by the intertextual references that give rise to humorous effect - creators vs. targets, the 'culturally literate' vs. the 'culturally illiterate' and those who agree vs. those who disagree with the ideological basis of humour. The paper elaborates the incongruity and superiority theories of humour, calling for a critical perspective on humorous genres and its utilisation in applied (educational) settings. Given that the exploration of intertextuality in the area of humour reveals that recipients with 'inadequate' literacy skills are disadvantaged in the processing of humour, the paper recommends steps that should be taken to enhance those skills in order to enable recipients to uncover discriminatory or marginalising meanings.

The second set of papers deals, broadly speaking, with genre renewal and change. In her article, Anastasiya Astapova analyses Soviet meta-jokes, focusing on the reflection of political and historical changes in joke-telling culture. Meta-jokes, understood here as jokes that refer to other jokes, are characterised by meta-discursivity and self-referentiality. They not only demarcate the symbolic boundaries between groups, but also provide social commentary, thus becoming a vehicle for constructing conspiratorial pleasure and conveying oral criticism. In this paper, an extensive dataset of Soviet meta-jokes, which often served as cautionary tales at that time, is presented diachronically across the entire $20^{\text {th }}$ century, with a special section devoted to their subsequent development during the post-Soviet situation. There is a distinct continuity of such jokes even after the fall of the Soviet Union, and the old themes and topics become recontextualised to suit new situations (e.g. in Belarus). 
The dimension of social criticism conveyed by intertextual references is also the subject of a paper by Ksenia Shilikhina. Shifting into the domain of technology-mediated communication, she discusses spoof news in online sources. Although spoof news is created according to journalistic conventions (and, thus, intertextually drawing on standard journalistic genres) and might appear to hold some potential for misinformation (particularly where the parodic treatment of a given issue is actually plausible), the paper argues that the genre is meant for the entertainment of readers. Nevertheless, there is more to such humoristic accounts than simple superficial entertainment: the various intertextual references can be used to undermine social norms, values, roles and patterns of behaviour, and thus hold serious social implications.

The third set of papers probes issues related to the transgression of social norms. Margherita Dore explores humour in advertising, identifying instances when intertextual humour is, for various reasons, risky. That occurs particularly where taboo or transgressive topics are involved, and the reception of humour may be unfavourable, having a boomerang effect on the advertiser. The paper interprets the failure of the intended humour as the result of the simultaneous exploitation of verbal and non-verbal intertextual references that activate multiple targets and scripts. It appears that, while advertisers work with various degrees of covertness/explicitness to create humour and draw attention to their brands, they may end up offending (at least part of) the audience. Such cases of failed humour in the advertising campaigns analysed in the text also show that advertisers misjudge the effects of negative reception, sometimes due to lack of understanding of the local socio-cultural contexts.

Another, very specific, form of negative reception of humour is explored by João Paulo Capelotti in the last article of this special issue. It concerns the disapproving reactions of political figures who object to various forms of humour targeting them. While parodies and memes have by now become omnipresent across the social media and the internet, so have the attempts of various public figures to control such creations. The article considers this situation from the point of view of copyright (e.g. the unauthorised use of images) against the fundamental principle of freedom of speech. The debate is illustrated with a case study from Brazil. However, Capelotti also warns, more generally, of the risks of a future unhindered production of content based on pre-existing forms that is under threat as a result of a recent directive adopted by the European Parliament (i.e. the 'meme killer directive'). The paper shows that intertexts and intertextual references, particularly as far as visual material in memes is concerned, are not unproblematic; in the near future, we are bound to see more debates about what kind of humour is permissible. The whole issue of humour and intertext is uneasily positioned among such lofty ideals as artistic creativity and freedom of expression, on the one hand, and more down-to-earth blocking factors such as copyright and personality protection, on the other.

As the outlines indicate, the papers in this special issue approach intertextuality in humour in relation to some traditional as well as novel humorous texts and genres (jokes, cartoons, digital communication, memes), while opening up some new vistas into future research. This is more than just a matter of academic interest, because the (in)ability to 'adequately' process intertextual references in humour and the debates over the '(in)appropriate' processing and interpretation of intertexts have significant social, political, legal, economical, etc. consequences, as we have tried to demonstrate here. This special issue makes a case for the need to pay close attention to the sociopragmatic functions of intertextual references in humorous texts. It is our contention that the applied dimension, be it in the area of critical literacy education, advertising and marketing communication, political discourse, media communication, or the legislative framework, constitutes a particularly salient and timely direction of future research. 


\section{Acknowledgements}

Most of the papers included in this special issue originate in a thematically related panel held at the 30th Conference of the International Society for Humour Studies in Tallinn, Estonia (2529 June 2018). We would like to thank the participants for their contributions, comments, and insights, as well as the conference organiser Liisi Laineste for having encouraged us to organise the panel.

\section{References}

Adami, E. (2012). 'The rhetoric of the implicit and the politics of representation in the age of copy-and-paste'. Learning, Media and Technology 37 (2), pp. 131-144.

Allen, G. (2000). Intertextuality. London: Routledge.

Antonopoulou, E., Nikiforidou, K. \& Tsakona, V. (2015). 'Construction grammar and discoursal incongruity', in Brône, G., Feyaerts, K. \& Veale, T. (eds.), Cognitive Linguistics and Humour Research, Berlin: De Gruyter Mouton, pp. 13-47.

Archakis, A., Lampropoulou, S., Tsakona, V. \& Tsami, V. (2015). 'Style and humour in Greek mass culture texts', in Brzozowska, D. \& Chłopicki, W. (eds.), Culture's Software: Communication Styles, Newcastle upon Tyne: Cambridge Scholars Publishing, pp. 16-38.

Attardo, S. \& Chabanne, J.-C. (1992). 'Jokes as a text type'. Humour: International Journal of Humour Research 5 (1/2), pp. 165-176.

Attardo, S. (1994). Linguistic Theories of Humour. Berlin: De Gruyter Mouton.

Attardo, S. (2001). Humorous Texts: A Semantic and Pragmatic Analysis. Berlin: De Gruyter Mouton.

Badarneh, M. A. (2020). “Like a donkey carrying books": Intertextuality and impoliteness in Arabic online reader responses'. Journal of Language Aggression and Conflict 8 (1), pp. 128.

Bakhtin, M. (1986). Speech Genres and Other Late Essays, trans. V. W. McGhee. Austin: University of Texas Press.

Barthes, R. (1967). 'The death of the author'. Retrieved June 21, 2020 from http://www.tbook.constantvzw.org/wp-content/death_authorbarthes.pdf.

Bauman, R. (2004). A World of Others' Words: Cross-cultural Perspectives on Intertextuality. Malden: Blackwell.

Bell, A. (2011). 'Re-constructing Babel: Discourse analysis, hermeneutics and the Interpretive Arc'. Discourse Studies 13 (5), pp. 519-568.

Bell, N. D. (2015). We Are Not Amused: Failed Humour in Interaction. Berlin: De Gruyter Mouton.

Bhatia, V. K. (2017). Critical Genre Analysis: Investigating Interdiscursive Performance in Professional Practice. London: Routledge.

Briggs, C. L. \& Bauman, R. (1992). 'Genre, intertextuality and social power'. Journal of Linguistic Anthropology 2 (2), pp. 131-172.

Brown, P. \& Levinson, S. C. (1987). Politeness: Some Universals in Language Usage. Cambridge: Cambridge University Press.

Chen, K. W. (2013). 'The Singapore Mass Rapid Transport: A case study of the efficacy of a democratised political humour landscape in a critical engagement in the public sphere'. European Journal of Humour Research 1 (2), pp. 43-68.

Chłopicki, W. (2020). 'Joke construction and joke structure', in Attardo, S. (ed.), Script-based Semantics: Foundations and Applications. Essays in Honour of Victor Raskin, Boston: De Gruyter Mouton, pp. 167-190. 
Chovanec, J. (2016). 'Eavesdropping on media talk: Microphone gaffes and unintended humour in sports broadcasts'. Journal of Pragmatics 95, pp. 93-106.

Chovanec, J. (2018). 'Irony as counter positioning: Reader comments on the EU migrant crisis', in Jobert, M. \& Sorlin, S. (eds.), The Pragmatics of Irony and Banter, Amsterdam: John Benjamins, pp. 165-194.

Chovanec, J. (in print). 'Saving one's face from unintended humour: Impression management in follow-up sports interviews'. Journal of Pragmatics.

Chovanec, J. \& Dynel, M. (2015). 'Researching interactional forms and participant structures in public and social media', in Dynel, M. \& Chovanec, J. (eds.), Participation in Public and Social Media Interactions, Amsterdam: John Benjamins, pp. 1-27.

Chovanec, J. \& Tsakona, V. (2018). 'Investigating the dynamics of humour: Towards a theory of interactional humour', in Tsakona, V. \& Chovanec, J. (eds.), The Dynamics of Interactional Humour: Creating and Negotiating Humour in Everyday Encounters, Amsterdam: John Benjamins, pp. 1-26.

Conradie, M. (2012). 'Anonymous vs. acknowledged intertexts: A relevance theoretic approach to intertextuality in print advertising'. Southern African Linguistics and Applied Language Studies 30 (3), pp. 293-310.

Constantinou, M. (2019). 'Charlie Hebdo's controversial cartoons in question: Stances, translational narratives and identity construction from a cross-linguistic perspective'. Social Semiotics 29 (5), pp. 698-727.

Coutinho, M. A. \& Miranda, F. (2009). 'To describe genres: Problems and strategies', in Bazerman, C., Bonini, A. \& Figueiredo, D. (eds.), Genre in a Changing World, Fort Collins: The WAC Clearinghouse and Parlor Press, pp. 35-55.

Davies, C. (2007). 'Humour and protest: Jokes under Communism'. International Review of Social History 52 (S15), pp. 291-305.

de Beaugrande, R. \& Dressler, W. (1981). Introduction to Text Linguistics. London: Longman.

Dynel, M. (2018). Irony, Deception and Humour: Seeking the Truth about Overt and Covert Untruthfulness. Boston: De Gruyter Mouton.

Dynel, M. \& Poppi, F. I. (2019). 'Risum teneatis, amici? The socio-pragmatics of RoastMe humor', Journal of Pragmatics 139, pp. 1-21.

El Refaie, E. (2009). 'What makes us laugh? Verbo-visual humour in newspaper cartoons', in Ventola, E. \& Guijarro, A. J. M. (eds.), The World Told and the World Shown, London: Palgrave Macmillan, pp. 75-89.

Fairclough, N. (1992). Discourse and Social Change. Cambridge: Polity Press.

Fairclough, N. (2000). 'Multiliteracies and language: Orders of discourse and intertextuality', in Cope, B. \& Kalantzis, M. (eds.), Multiliteracies: Literacy Learning and the Design of Social Futures, London: Routledge, pp. 159-178.

Flowerdew, J. \& Wang, S. (2015). 'Identity in academic discourse'. Annual Review of Applied Linguistics 35, pp. 81-99.

Gasparov, B. (2010). Speech, Memory and Meaning: Intertextuality in Everyday Language. Berlin: De Gruyter Mouton.

Hale, A. (2018a). "I get it, but it's just not funny": Why humour fails, after all is said and done'. The European Journal of Humour Research 6 (1), pp. 36-61.

Hale, A. (2018b). 'There is an after-life (for jokes, anyway): The potential for, and appeal of, "immortality" in humour'. Humour: International Journal of Humour Research 31 (3), pp. 507-538.

Kotthoff, H. (2002). 'Irony, quotation, and other forms of staged intertextuality', in Graumann, C. F. \& Kallmeyer, W. (eds.), Perspective and Perspectivation in Discourse, Amsterdam: John Benjamins, pp. 201-233. 
Kramer, E. (2011). 'The playful is political: The metapragmatics of internet rape-joke arguments'. Language in Society 40 (2), pp. 137-168.

Krikmann, A. (2009). 'Jokes in Soviet Estonia'. Folklore: Electronic Journal of Folklore 43, pp. 43-66.

Kristeva, J. (1980), Desire in Language: A Semiotic Approach to Literature and Art, trans. L. S. Roudiez. Oxford: Blackwell.

Kuipers, G. (2020). 'Knowledge about humour', in Attardo, S. (ed.), Script-based Semantics: Foundations and Applications. Essays in Honour of Victor Raskin, Boston: De Gruyter Mouton, pp. 93-113.

Laineste, L. \& Voolaid, P. (2016). 'Laughing across borders: Intertextuality of internet memes'. European Journal of Humour Research 4 (4), pp. 26-49.

Laineste, L. (2011). 'Politics of taste in a post-Socialist state: A case study', in Tsakona, V. \& Popa, D. E. (eds.), Studies in Political Humour: In between Political Critique and Public Entertainment, Amsterdam: John Benjamins, pp. 217-241.

Lewis, P. (ed.) (2008). The Muhammad Cartoons and Humour Research: A Collection of Essays. Humour: International Journal of Humour Research 21 (1), pp. 1-46.

Mazurek-Przybylska, B. (2016). 'Intertextual face of humour: A case study of Lauren Cooper Meets Dr Who'. Israeli Journal of Humour Research 5 (1), pp. 80-94.

Norrick, N. R. (1989). 'Intertextuality in humour'. Humour: International Journal of Humour Research 2 (2), pp. 117-139.

Norrick, N. R. (1993). Conversational Joking: Humour in Everyday Talk. Bloomington: Indiana University Press.

Norrick, N. R. \& Chiaro, D. (eds.) (2009). Humour in Interaction. Amsterdam: John Benjamins.

Piata, A. (2018). 'On-line humorous representations of the 2015 Greek national elections: Acting and interacting about politics on social media', in Tsakona, V. \& Chovanec, J. (eds.), The Dynamics of Interactional Humour: Creating and Negotiating Humour in Everyday Encounters, Amsterdam: John Benjamins, pp. 258-282.

Piata, A. (to appear). 'Stylistic humour across modalities: The case of Classical Art memes'. Internet Pragmatics.

Popa, D. E. (2011). 'Political satire dies last: A study on democracy, opinion formation, and political satire', in Tsakona, V. \& Popa, D. E. (eds.), Studies in Political Humour: In between Political Critique and Public Entertainment, Amsterdam: John Benjamins, pp. 137-165.

Raskin, V. (1985). Semantic Mechanisms of Humour. Dordrecht: D. Reidel.

Ross, A. (1998). The Language of Humour. London: Routledge.

Sacks, H. (1974). 'An analysis of the course of a joke's telling in conversation', in Bauman, R. \& Sherzer, J. (eds.), Explorations in the Ethnography of Speaking, Cambridge: Cambridge University Press, pp. 337-353.

Sherzer, J. (1985). 'Puns and jokes', in van Dijk, T. A. (ed.), Handbook of Discourse Analysis, Vol. 3, Discourse and Dialogue, London: Academic Press, pp. 213-221.

Shifman, L. (2014). Memes in Digital Culture. Cambridge: MIT Press.

Smith, M. (2009). 'Humour, unlaughter, and boundary maintenance'. Journal of American Folklore 122 (484), pp. 148-171.

Tsakona, V. (2009). 'Language and image interaction in cartoons: Towards a multimodal theory of humour'. Journal of Pragmatics 41 (6), pp. 1171-1188.

Tsakona, V. (2017a). "Democracy is 4 wolves and 1 sheep voting for food": Analysing jokes about politicians in the financial crisis', in Georgakopoulos, T., Pavlidou, T.-S., Pechlivanos, M., Alexiadou, A., Androutsopoulos, J., Kalokairinos, A., Skopeteas, S. \& Stathi, K. (eds.), Proceedings of the 12th International Conference on Greek Linguistics, 
Volume 2, Berlin: Romiosini, pp. 1035-1049. Retrieved August 17, 2019 from http://www.cemog.fu-berlin.de/en/icgl12/offprints/tsakona/icgl12_Tsakona.pdf. [in Greek]

Tsakona, V. (2017b). 'Genres of humour', in Attardo, S. (ed.), The Routledge Handbook of Language and Humour, New York: Routledge, pp. 489-503.

Tsakona, V. (2017c). 'Humour research and humour reception: Far away, so close', in Chłopicki, W. \& Brzozowska, D. (eds.), Humorous Discourse, Berlin: De Gruyter Mouton, pp. 179-201.

Tsakona, V. (2017d). “This is not a political party, this is Facebook!": Political jokes and political (mis)trust in crisis-ridden Greece'. European Journal of Humour Research 5 (4), pp. 136-157.

Tsakona, V. (2018a). 'Intertextuality and cultural literacy in contemporary political jokes', in Sover, A. (ed.), The Languages of Humour: Verbal, Visual, and Physical Humour, London: Bloomsbury Academic, pp. 86-104.

Tsakona, V. (2018b). 'Intertextuality and/in political jokes'. Lingua 203, pp. 1-15.

Tsakona, V. (2018c). 'Online joint fictionalisation', in Tsakona, V. \& Chovanec, J. (eds.), The Dynamics of Interactional Humour: Creating and Negotiating Humour in Everyday Encounters, Amsterdam: John Benjamins, pp, 229-255.

Tsakona, V. (2019). 'Re-contextualising the linguistic theory of humour'. Plenary talk at the 31 st Conference of the International Society for Humour Studies, University of Texas at Austin, USA, 24-28 June.

Tsakona, V. (2020a). Recontextualising Humour: Rethinking the Analysis and Teaching of Humour. Boston: De Gruyter Mouton.

Tsakona, V. (2020b). 'Tracing the trajectories of contemporary online joking'. Media Linguistics/Медиалингвистика 7 (2), pp. 169-183.

Tsakona, V. \& Chovanec, J. (eds.) (2018). The Dynamics of Interactional Humor: Creating and Negotiating Humour in Everyday Interactions. Amsterdam: John Benjamins.

Tsakona, V. \& Tsami, V. (in prep.). "'Did you hear the crunch sound?": Humour and metapragmatic stereotypes in the Greek Master Chef contest'.

Tsiplakou, S. \& Ioannidou, E. (2012). 'Stylising stylisation: The case of Aigia Fuxia'. Multilingua 31 (2), pp. 277-299.

Vásquez, C. (2018). Language, Creativity and Humour Online. London: Routledge.

Watters, C. (2011). 'Being Berlusconi: Sabina Guzzanti's impersonation of the Italian Prime Minister between stage and screen', in Tsakona, V. \& Popa, D. E. (eds.), Studies in Political Humour: In between Political Critique and Public Entertainment, Amsterdam: John Benjamins, pp. 167-189.

Werner, W. (2004). 'On political cartoons and social studies textbooks: Visual analogies, intertextuality, and cultural memory'. Canadian Social Studies 38 (2). Retrieved August 17, 2019 from https://files.eric.ed.gov/fulltext/EJ1073912.pdf.

Yus, F. (2018). 'Identity-related issues in meme communication'. Internet Pragmatics 1 (1), pp. 113-133. 